\title{
Typification of Names in Ancistrocladus Wallich (Ancistrocladaceae)
}

\author{
Roy E. Gereau \\ Missouri Botanical Garden, P.O. Box 299, St. Louis, Missouri 63166-0299, U.S.A.
}

ABstract. Details of typification are presented for 25 of the 27 existing binomials in Ancistrocladus Wallich (Ancistrocladaceae). Holotypes are indicated for A. carallioides Craib, A. congolensis J. Léonard, A. ealaensis J. Léonard, A. extensus Wallich ex Planchon, A. griffithii Planchon, A. guineensis Oliver, Wormia hamata Vahl [ $\equiv$ A. hamatus (Vahl) Gilg, A. vahlii Arnott], A. harmandii Gagnepain, A. heyneanus Wallich ex J. Graham, A. korupensis D. W. Thomas \& Gereau, A. letestui Pellegrin, A. likokoi J. Léonard, A. pachyrrhachis Airy Shaw, A. pinangianus Wallich ex Planchon, A. robertsoniorum J. Léonard, Bembix tectoria Loureiro [ $\equiv$ A. tectorius (Loureiro) Merrill], A. thwaitesii Tieghem, A. uncinatus Hutchinson \& Dalziel, and A. wallichii Planchon. Previously designated lectotypes are indicated for A. abbreviatus Airy Shaw and A. barteri Scott-Elliot, lectotypes are newly designated for $A$. attenuatus Dyer and A. cochinchinensis Gagnepain, and the probable need for neotypification of $A$. hainanensis Hayata is discussed. Two names, $A$. pentagynus Warburg and A. sagittatus Wallich ex Planchon, are excluded from the genus.

Ancistrocladus Wallich (Ancistrocladaceae) is a genus of approximately 20 known species, 9 in tropical Asia and 11 in tropical Africa (Thomas \& Gereau, 1993). Twenty-seven binomials have been published in the genus, but subsequent to the synopsis presented by Gilg (1925), no overview of Ancistrocladus throughout its range has appeared. In anticipation of the monograph of the genus now in progress, details of typification of 25 binomials in Ancistrocladus are provided, while 2 binomials are excluded from the genus. Although references to published taxonomic synonymy of some of the Asian species are included in the discussions of individual names, no attempt is made to elucidate taxonomic relationships in the present work.

Although the genus Ancistrocladus is conserved as a nomen novum published by Wallich (18281849), the binomials first proposed in that work were not validated by descriptions and are thus nomina nuda unless they were subsequently effectively and validly published (de Candolle \& Rad-
cliffe-Smith, 1981: 345). In a number of cases, type specimens have been indicated in the following format:

Ancistrocladus extensus Wallich ex Planchon, Ann. Sci. Nat. Bot., Sér. 3, 13: 318. 1849. TYPE: "Amherst, prov. Martaban" (Burma) [Wallich, Numer. List 1052.1. 1829] (holotype, $\mathrm{K}$; isotypes, BM, K, K-WALL).

In this example, the authorities and first literature citation refer to the validation by Planchon in 1849 of a binomial proposed by Wallich. The type locality in quotations is as written on the isotype in K-WALL (the Herbarium of the Honourable East India Company, maintained as a separate collection at $\mathrm{K}$ ) and interpreted by Planchon. The citation in square brackets is a reference to both the set of specimens distributed as Wallich 1052.1 and to the publication of the epithet in the Numerical List in 1829. As explained by de Candolle and RadcliffeSmith (1981: 344), the specimens now housed in K-WALL are unlikely to have been the duplicates available to most authors who validated Wallich's names; the K-WALL duplicates have thus been considered isotypes rather than holotypes in all of the following cases.

\section{NOMENCLATOR}

Ancistrocladus Wallich, Numer. List. 1052. 1829. (Nom. conserv.) TYPE (listed in ICBN Appendix IIIA and thus protected under Art. 14.8): Ancistrocladus hamatus (Vahl) Gilg ( $\equiv$ Wormia hamata Vahl).

$\equiv$ Wormia Vahl, Skr. Naturhist.-Selsk. 6: 105. 1810 (hom. illegit., non Wormia Rottboell [Dilleniaceae], Nye Saml. Kongel. Danske Vidensk. Selsk. Skr. 2: 532. 1783).

$=$ Bembix Loureiro, Fl. cochinch. 259, 282. 1790. (Nom. rejic.) TYPE: Bembix tectoria Loureiro

Note. In the following citations, names of collectors appear under each binomial exactly as published in the protologue. In discussions of specimens following the formal citations, names appear as written on herbarium labels. 
Ancistrocladus abbreviatus Airy Shaw, Kew Bull. 1949: 67. 1949. TYPE: Sierra Leone. Njala, Deighton 2589 (lectotype, designated by Airy Shaw (Kew Bull. 1950: 148. 1950), K; isolectotypes, BM, P).

Ancistrocladus attenuatus Dyer, in Hooker f., Fl. Brit. India 1: 300. 1874. TYPE: Tenasserim and Andaman Islands, Helfer s.n., Kew Distrib. 724 (lectotype, designated here, $\mathrm{K}$; isotypes, C, GH, K, L, P).

At $\mathrm{K}$ there are two specimens identically labeled "Herbarium of the late East India Company No. 724, Ancistrocladus attenuatus Dyer, TENASSERIM and ANDAMANS. Herb. Helfer. Distributed at the Royal Gardens, Kew. 1861-2." Both bear a red "Type Specimen" label and are stamped "HERBARIUM HOOKERIANUM 1867." I here designate the specimen with a detached infructescence bearing fruits with partially developed wings as the lectotype.

Ancistrocladus barteri Scott-Elliot, J. Linn. Soc., Bot. 30: 73. 1894. TYPE: Sierra Leone. Mount Gonkwi, Duunia, Talla Hills, Scott Elliot 4860 (lectotype, designated by Airy Shaw (Kew Bull. 1950: 148. 1950), K; isolectotype, BM).

Ancistrocladus carallioides Craib, Bull. Misc. Inform. 1925: 19. 1925. TYPE: Thailand. Nan: Doi Tiu, Kerr 5053 (holotype, K; isotype, BM).

Ancistrocladus cochinchinensis Gagnepain, Notul. Syst. (Paris) 1: 115. 1909. SYNTYPES: Vietnam. Bin dinh, Pierre 16 (lectotype, designated here, $\mathrm{P}[\mathrm{fl}]$; isolectotypes, $\mathrm{A}, \mathrm{C}, \mathrm{K}, \mathrm{L}$, $\mathrm{P}$ [fr], US); Prov. Bien hoa, Tri huyen, Pierre 1716 (not seen), 1731 (A, C, L, P), 1732 (K, $\mathrm{P})$.

None of the syntypes examined was in conflict with the description in the protologue of Ancistrocladus cochinchinensis, and so I have designated the highest quality duplicate of the most widely distributed collection as the lectotype. At $\mathrm{P}$ there are two specimens labeled Pierre 16, one in late flower and one in fruit. The fruiting specimen bears the locality data "in sylvis ad Tri in prov. Bien Hoa," corresponding to the locality given by Gagnepain for Pierre 1716, 1731, and 1732. The flowering specimen bears the locality "in montibus Binh Dinh," in agreement with the locality given in the protologue for Pierre 16. I therefore have designated the flowering specimen at $\mathrm{P}$ as the lectotype.
Ancistrocladus congolensis J. Léonard, Bull. Soc. Roy. Bot. Belgique 82: 33. 1949. TYPE: Zaïre. Forestier Central, Yafunga sur Zaïre, près d'Isangi, Louis 11171 (holotype, BR; isotypes, BM, BR, K, P).

At BR there are two specimens labeled Louis 11171 , both in good condition and with mature fruit. The specimen with a typewritten label and annotated "Ancistrocladus congolensis J. Léonard, Determinavit Léonard $12 / 48$ et $3 / 1982$ " is here considered the holotype, while the specimen with a handwritten label and no dated annotation is here considered an isotype.

Ancistrocladus ealaensis J. Léonard, Bull. Soc. Roy. Bot. Belgique 82: 30. 1949. TYPE: Zaïre. Forestier Central, env. d'Eala, rivière Yuli, J. Léonard 1057 (holotype, BR; isotypes, BR, K, $\mathrm{P}$, YBI not seen).

At BR there are two specimens labeled J. Léonard 1057. As for Ancistrocladus congolensis, the specimen bearing a typewritten label and a dated annotation by Léonard is here considered the holotype.

Ancistrocladus extensus Wallich ex Planchon, Ann. Sci. Nat. Bot., Sér. 3, 13: 318. 1849. TYPE: "Amherst, prov. Martaban" (Burma) [Wallich, Numer. List 1052.1. 1829] (holotype, $\mathrm{K}$; isotypes, BM, K, K-WALL).

The holotype of Ancistrocladus extensus is the specimen at $\mathrm{K}$ stamped "HERBARIUM HOOKERIANUM 1867" and bearing a lithographed label from Wallich's Numerical List on which is written "1052 Ancistrocladus extensus, Wall Ad hoc genus pertinet Wormia, Vahl in act. soc. hist. nat. hafn. vol 6. p 104 (haud Rottb.) 1 Amherst 18272 Pundua, F. D Silva. An ullo modo distinctus?"

An identically labeled specimen in K-WALL bears a microfiche number 1052.1, corresponding to the type locality of $A$. extensus and the first numbered locality on Wallich's label. Van Steenis (1948) considered $A$. extensus a taxonomic synonym of A. tectorius.

Ancistrocladus griffithii Planchon, Ann. Sci. Nat. Bot., Sér. 3, 13: 318. 1849. TYPE: "Mergui" (Burma), Griffith s.n. (holotype, K; isotype, P).

Ancistrocladus guineensis Oliver, Fl. trop. Afr. 1: 175. 1868. TYPE: Nigeria. Calabar, Mann 2234 (holotype, $\mathrm{K}$; isotypes, GH, P). 
Ancistrocladus hainanensis Hayata, Icon. pl. formos. 3: 46. 1913. TYPE: Hainan, Z. Katsumada s.n. (not seen).

After examining material on loan from a large number of herbaria, including KYO, SING, and TI, I have not found the above-cited type. I prefer to delay the neotypification of Ancistrocladus hainanensis until all materials have been examined for the monograph of the genus. Van Steenis (1948) considered A. hainanensis a taxonomic synonym of A. tectorius.

Ancistrocladus hamatus (Vahl) Gilg, Nat. Pflanzenfam. 3(6): 276. 1895. Wormia hamata Vahl, Skr. Naturhist.-Selsk. 6: 105. 1810. Ancistrocladus vahlii Arnott, Nova Acta Phys.-Med. Acad. Caes. Leop.-Carol. Nat. Cur. 18: 325. 1836. Nom. superfl. illegit. TYPE: Sri Lanka, près de Bigamen, Koenig s.n. (holotype, C; isotypes, A, C, BM, L, P).

At $\mathrm{C}$ there are three specimens filed in the type folder of Wormia hamata and labeled "Recorded in the catalogue of the Koenig collections." The specimen stamped "HB. VAHLII" bears both extensive annotations in Vahl's hand (compared with Vahl sample $f$ in Burdet, 1979) and a sketch of the plant's habit, and is here considered the holotype.

Ancistrocladus harmandii Gagnepain, Notul. Syst. (Paris) 1: 114. 1909. TYPE: Laos. Koukou: bassin du Sé-moun, Harmand 989 (holotype, $\mathrm{P}$; isotype, $\mathrm{K}$ ).

Ancistrocladus heyneanus Wallich ex J. Graham, Cat. pl. Bombay 28. 1839. TYPE: "Herb. Heyne" [Wallich, Numer. List 7262. 1832] (holotype, $\mathrm{K}$; isotypes, $\mathrm{C}$, K-WALL).

Ramamoorthy (1976) suggested that Ancistrocladus heyneanus may be a taxonomic synonym of $A$. hamatus.

Ancistrocladus korupensis D. W. Thomas \& Gereau, Novon 3: 494. 1993. TYPE: Cameroon. Southwest Prov.: Ndian Div., 0.6 km E of confluence of Mededibe (Moliba) and Ndian (Mana) Rivers, Gereau et al. 5180 (holotype, $\mathrm{MO}$; isotypes, $\mathrm{K}, \mathrm{P}, \mathrm{SCA}, \mathrm{YA}$ ).

Ancistrocladus letestui Pellegrin, Bull. Soc. Bot. France 98: 18. 1951. TYPE: Gabon. Lastoursville: monts Iboundji, LeTestu 8627 (holotype, $\mathrm{P}$; isotypes, BM, BR, EA).
Ancistrocladus likokoi J. Léonard, Bull. Soc. Roy. Bot. Belgique 82: 34. 1949 [as "likoko"]. TYPE: Zaïre. Forestier Central, rivière Boamba, env. de Yangambi, J. Léonard 1850 (holotype, BR; isotypes, BR, P, YBI not seen).

In the protologue, Léonard stated, "Cette espèce est dédiée au brave LIKOKO, indicateur à la Division de Botanique de l'INÉAC à Yangambi." It is thus necessary under ICBN Art. 60.11 (Greuter et al., 1994: 74) to correct the orthography of the specific epithet as above. There are three specimens at BR labeled J. Léonard 1850. As in the case of Ancistrocladus congolensis and A. ealaensis, the specimen bearing a typewritten label and a dated annotation by Léonard is here considered the holotype.

Ancistrocladus pachyrrhachis Airy Shaw, Kew Bull. 1950: 149. 1950. TYPE: Liberia. Montserrado: Monrovia, J. T. Baldwin Jr. 5839 (holotype, K [Sheet 1]; isotypes, K [Sheets 2-4]).

At $\mathrm{K}$ there are four specimens labeled J. T. Baldwin 5839. The upper right corner of each label is marked with a handwritten sheet number. Sheet 1 , bearing Airy Shaw's handwritten annotation dated 6.ix.49 and a red "Type Specimen" label, is here considered the holotype.

Ancistrocladus pinangianus Wallich ex Planchon, Ann. Sci. Nat. Bot., Sér. 3, 13. 318. 1849. TYPE: Penang (Malaysia), G. Porter s.n. [Wallich, Numer. List 1054. 1829] (holotype, $\mathrm{K}$; isotypes, $\mathrm{BR}, \mathrm{C}, \mathrm{K}, \mathrm{K}-\mathrm{WALL}, \mathrm{P}$ ).

The specimen at $\mathrm{K}$ bearing Wallich's lithographed label number 1054 and stamped "HERBARIUM HOOKERIANUM 1867" is here considered the holotype of Ancistrocladus pinangianus. Another specimen at $\mathrm{K}$ with the handwritten annotation "Ancistrocladus Penangianus Wall, Penang Wallich 1829, H. I. 1054" and stamped "HERBARIUM BENTHAMIANUM 1854" is an isotype. Van Steenis (1948) considered A. pinangianus a taxonomic synonym of A. tectorius.

Ancistrocladus robertsoniorum J. Léonard, Bull. Jard. Bot. Belg. 54: 466. 1984. TYPE: Kenya. Kwale Dist.: Buda Forest, Robertson 3687 (holotype, BR; isotype, BR).

At BR there are two specimens labeled $S$. A. Robertson 3687. As in the case of Ancistrocladus congolensis, A. ealaensis, and A. likokoi, the specimen with a typewritten label and a dated annotation by Léonard is here considered the holotype. 
Ancistrocladus tectorius (Loureiro) Merrill, Lingnan Sci. J. 6: 329. 1930. Bembix tectoria Loureiro, Fl. cochinch. 282. 1790. TYPE: Vietnam, Loureiro s.n. (holotype, BM).

I have examined the specimen identified by Moore (1927) as the holotype of Bembix tectoria and find no reason to dispute his conclusion.

Ancistrocladus thwaitesii Tieghem, J. Bot. (Morot) 17: 154. 1903. TYPE: Sri Lanka, Thwaites 1600 (holotype, P; isotypes, BM, BR, GH, HAKS, K, L, SING, US).

At $\mathrm{P}$ there are three specimens labeled Thwaites 1600. Only one specimen has a label printed "CEYLAN. M. Thwaites, 1854. No." followed by a handwritten "1600"; this specimen is here considered the holotype. Harriman (1987) considered Ancistrocladus thwaitesii a taxonomic synonym of $A$. hamatus.

Ancistrocladus uncinatus Hutchinson \& Dalziel, Fl. W. trop. Afr., ed. 1, 1: 196. 1927. TYPE: Nigeria. Eket, Talbot 3108 (holotype, K; isotype, BM).

Ancistrocladus wallichii Planchon, Ann. Sci. Nat. Bot., Sér. 3, 13: 319. 1849. TYPE: "Pundua," F. de Sylva s.n. [Wallich, Numer. List 1052.2. 1829] (holotype, K; isotypes, C, GH, K-WALL).

The specimen in K-WALL bearing microfiche number 1052.2 is otherwise labeled "A. extensus, Wall. Is this the same precisely as this type from Amherst?". The specimen in K has an inflorescence structure virtually identical to that of the K-WALL specimen and has similarly immature fruits. It is labeled "Ancistrocladus extensus Wall, Amherst Wallich 1829, H. I. 1052," and is stamped "HERBARIUM BENTHAMIANUM 1854." The label of the isotype of $A$. wallichii at GH bears a partial marking "BENTHAMIANUM" with what appears to be the lower half of the same stamp. From the above evidence I conclude that the specimen in K represents Wallich's number 1052.2 and is the holotype of $A$. wallichii.

\section{ExCluded Names}

Ancistrocladus pentagynus Warburg, Bot. Jahrb. Syst. 13: 383. 1891. TYPE: not designated.

Van Steenis (1948) cited Hallier (1923: 77) in considering this a species of Durandea Planchon (Linaceae).
Ancistrocladus sagittatus Wallich ex Planchon; Ann. Sci. Nat. Bot., Sér. 3, 13: 319. 1849. TYPE: Singapore [Wallich, Numer. List 1055. 1829].

Van Steenis (1948) placed this name in synonymy with Tetramerista glabra Miquel (Tetrameristaceae).

Acknowledgments. For the loan of herbarium specimens including most of the types cited above, I thank the curators and staff of A, BM, BR, C, EA, GH, HAKS, K, KYO, L, P, SCA, SING, TI, US, and YA. I am particularly grateful to the staff of $\mathrm{K}$ for a superb set of Cibachrome prints of type specimens. For hospitality and useful discussions during a brief visit to K in April 1996, I thank Nicolas Hind, Alan Radcliffe-Smith, and Yvette Harvey. I am most especially indebted to Charlotte M. Taylor (MO) for critical reading of the manuscript, and to James S. Miller (MO) for logistical support and discussion of nomenclatural problems.

\section{Literature Cited}

Burdet, H. M. 1979. Auxilium ad botanicorum graphicem. Conservatoire et Jardin botaniques, Geneva.

Candolle, R. de \& A. Radcliffe-Smith. 1981. Nathaniel Wallich, MD, PhD, FRS, FLS, FRGS, (1786-1854) and the Herbarium of the Honourable East India Company, and their relation to the de Candolles of Geneva and the Great Prodromus. Bot. J. Linn. Soc. 83: 325-348.

Gilg, E. 1925. Ancistrocladaceae. Nat. Pflanzenfam. ed. 2, 21: 589-592.

Greuter, W., F. R. Barrie, H. M. Burdet, W. G. Chaloner, V. Demoulin, D. L. Hawksworth, P. M. Jørgensen, D. H. Nicolson, P. C. Silva, P. Trehane \& J. McNeill. 1994. International Code of Botanical Nomenclature (Tokyo Code). Regnum Veg. 131.

Hallier, H. 1923. Beiträge zur Kenntnis der Linaceae (DC. 1819) Dumort. Beih. Bot. Centralbl. 39(2): 1-178.

Harriman, N. A. 1987. Ancistrocladaceae. In: M. D. Dassanayake (editor), Flora of Ceylon 6: 1-2. Amerind Publishing, New Delhi.

Moore, S. 1927. Notes on two species of Loureiro's Flora cochinchinensis: Bembix Lour. J. Bot. 65: 279-280.

Ramamoorthy, T. P. 1976. Ancistrocladaceae. Pp. 171172 in C. J. Saldanha \& D. H. Nicolson (editors), Flora of Hassan District, Karnataka, India. Amerind Publishing, New Delhi.

Steenis, C. G. G. J. van. 1948. Ancistrocladaceae. In: C. G. G. J. van Steenis (editor), Flora Malesiana, Ser. 1, 4: 8-10, Noordhoff-Kolff N.V., Batavia.

Thomas, D. W. \& R. E. Gereau. 1993. Ancistrocladus korupensis (Ancistrocladaceae): A new species of liana from Cameroon. Novon 3: 494-498.

Wallich, N. 1828-1849. A numerical list of dried specimens of plants in the East India Company Museum, collected under the superintendence of Dr. Wallich of the Company's Botanic Garden at Calcutta. Lithographed manuscript, London. 


\section{$2 \mathrm{BHL}$ Biodiversity Heritage Library}

Gereau, Roy E. 1997. "Typification of Names in Ancistrocladus Wallich (Ancistrocladaceae)." Novon a journal of botanical nomenclature from the Missouri Botanical Garden 7, 242-245. https://doi.org/10.2307/3391935.

View This Item Online: https://www.biodiversitylibrary.org/item/14667

DOI: https://doi.org/10.2307/3391935

Permalink: https://www.biodiversitylibrary.org/partpdf/121783

\section{Holding Institution}

Missouri Botanical Garden, Peter H. Raven Library

\section{Sponsored by}

Missouri Botanical Garden

\section{Copyright \& Reuse}

Copyright Status: In copyright. Digitized with the permission of the rights holder.

License: http://creativecommons.org/licenses/by-nc-sa/3.0/

Rights: https://biodiversitylibrary.org/permissions

This document was created from content at the Biodiversity Heritage Library, the world's largest open access digital library for biodiversity literature and archives. Visit BHL at https://www.biodiversitylibrary.org. 